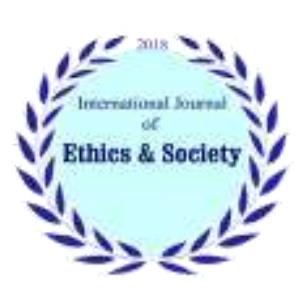

International Journal of Ethics \& Society (IJES)

Journal homepage: $\underline{\text { www.ijethics.com }}$

Vol. 2, No. $\mathbf{3 ( 2 0 2 0 )}$

(Original article)

\title{
Developing the Moral Codes of Teachers in Islam: Synthesis Research Based on the Roberts's Model
}

\section{Meysam Gholampour ${ }^{\mathrm{a}}$, Hadi Pourshafei ${ }^{\mathrm{b} *}$, Maghsoud Farasatkhah ${ }^{\mathrm{C}}$, Mohsen Ayati $^{\mathrm{b}}$}

\author{
a) Ph.D. Student in Curriculum Planning, University of Birjand, Birjand, Iran. \\ b) Dept. of Educational Science, Faculty of Educational Sciences \& Psychology, University of Birjand, Birjand, Iran. \\ c) Dept. of Planning in Higher Education, Institute for Research and Planning in Higher Education, Iran.
}

\section{Abstract}

Background: In Islam, expectations are very high in respect to a desirable teacher, especially because the teacher is a model for the next generation, so the purpose of this study is to identify the moral codes of teachers according to the Islamic perspective.

Method: The approach of the present study is qualitative and its method is synthesis research. The research population is all articles (63 articles) that have been presented from 2010 to 2020 in the field of moral components of educators from the perspective of the Holy Quran and the educational life of Imams (A) and the Prophet Mohammad (S). The research sample includes 26 articles, which have been purposefully selected based on thematic monitoring and theoretical data saturation. Research data were collected from qualitative analysis of the studied documents.

Results: The results showed that the moral codes of teachers from the perspective of Islam can be organized in two main dimensions including: contextual dimension (including personality components, insight, religious commitment, socio-political factors and neatness) and professional dimension (including components of professional commitment, knowledge enhancement, professional principles, interactions, content management, teaching and evaluation).

Conclusion: According to the principles of Islam, the components of teachers' professional ethics were organized in two contextual and professional dimensions, so the managers of educational organizations can provide in-service courses for teachers to teach the components of ethics and also design a moral code of ethics taking into account the moral components of teachers in Islam.

Keywords: Moral codes, Islam, Roberts's model

* Corresponding Author: Emailıِ Hpourshafei@birjand.ac.ir

Received: 21 Nov 2020

Accepted: 19 Dec 2020

24

Available at: www.ijethics.com 


\section{Introduction}

In all divine religions, attention to education has been of paramount importance. Islam has always paid special attention to education and the essentiality of education and training methods has been referred to in the Holy Quran and the narrations of Prophet Mohammad and the Imams (a) of Shi'a (1). Education, which results in the ultimate growth and development of human beings, is the principal aim of the consigning the prophets and the holy books (2). Prophet Mohammad declared teaching as his prophethood purpose (3). Also, in many verses of the Qur'an, God has introduced himself as a teacher. For example, God asserts in Surah Ar-Rahman: "God, the Merciful, has taught the Qur'an." Meantime, the divine religions, through their prophets and divine books, have paid attention to the institutionalization of morality in the early societies more than any educational program.

Educational programs, in an aim to nurture human beings, are based on moral considerations more than anything else (4). The morality acts as a wardsoff for the humanity deeds against any desire and inclination toward perversion (5). Education is regarded as a sacred duty in society, and its sanctity compels teachers to take morality values into considerations (6). Teaching is a moral profession (7) and the teacher is known as a moral person (8). Teachers' implicit beliefs and their teaching ethics affect students (9). However, the consequences of teachers' moral behavior are of no certainty to themselves (10). Adherence of professors and teachers to the principles of professional ethics is of utmost importance in respect to different perspectives, such as development of an organizational culture based on ethics; passing on distinctive traits and outstanding human characteristics to learners and, consequently, its dissemination in society (11). Professional ethics in educational systems defines the limits of appropriate or inappropriate behaviors and helps to guide the teacher in fulfilling professional responsibilities (12).

Teachers are the most important actors in wellknown educational systems (13) and are a key element in the process of implementing educational curricula (14). Improving teacher quality is a key element in improving education (15). In other words, no educational system can develop to an advanced level beyond the professional capacity of its teachers (16). Various studies in the field of professional ethics of teachers displays teachers' performance weakness in this field (17).

Professional Ethics is a branch of Ethics and it brings about stability and agreement between the two material and immaterial aspects of humanity (18). Each collection has its moral codes appropriate for its professional structure that are named professional ethics (19). The main purpose of these moral codes is self-criticization and the nurturance that it entails (20). The study of business ethics attracted the attention of the humanities from the 1950s onward (21). Professional ethics are behavioral principles set by individuals in a particular profession (20). Professional ethics deals with issues, principles and moral values governing a professional system (22) as well as the politeness of an individual and the action $\mathrm{s} /$ he takes when doing professional work (23).

Today, the behavior of teachers is of utmost importance to people (24). Parents and educational policymakers expect teachers to take note of ethical principles (25). The professional ethics of teachers have been focused on in most countries of the world during the recent decades (26). Teachers are human resources whose hands form public opinion and whose eyes see the perspective of cultural and scientific development of society. Also, to perform moral norms of a society, they have a duty beyond others (27). Strenuous efforts are needed to improve education, develop professional ethics and increase teachers' knowledge in this field (24).

In the divine religions, the characteristics and ethics of teachers are also of considerate importance (28). A simple reading of the verses of the Qur'an can show why and to what extent teachers are of dignity; teaching is the role of God and also as the reason behind coming of the prophets, and God states in the Qur'an that the prophets are the other teachers of man who teach man the Holy Book and Wisdom and prepare them for social and legal life. On 
the other hand, the practical behaviors of the Infallible Imams, according to the Verse of Purification and other Islamic narrations, is among the richest sources for an elicitation of the educational components and factors that have not been researched yet (29).

According to Unio, knowledge of the principles and components of professional ethics provides the context for the teachers to follow them (6). According to what referred to hitherto, in recent research, there have been developed numerous and disparate codes and ethical components in the field of professional ethics of teachers and instructors, however, less attention has been paid to the ethical components in the view of Islam. Therefore, in this research, we have an aim to summarize the results of research conducted in respect to teachers' moral characteristics from the perspective of the Holy Quran and the Imams (a) of Shi'a, utilizing a research synthesis approach.

\section{Material and Methods}

The present research method is research synthesis, which deals with a combination of specific features and factors of the research literature. In some cases, research synthesis is known as qualitative metaanalysis and tries to analyze the research it covers and resolve the contradictions in them. Meanwhile, as it integrates the results, it identifies the main topics for future research (30). Therefore, the field of research includes all valid scientific articles in the field of professional ethics of teachers from the perspective of the Holy Quran and the practical behaviour of the Imams (a) of Shi'a. To provide the required information, the worksheet form designed by the researcher was used to report and record the information of the initial research.

In order to analyze the existing scientific documents in this field, we employed content analysis, which uses categorization. The data obtained from this study were analyzed based on three coding principles: open, axial and selective. In this way, first through open coding, the categories were extracted from the documents, and then by grouping the same open codes in one category, the axial codes of the research were extracted. Finally, the identified axial codes were placed together in their appropriate dimensions and the selection codes were extracted. In the present study, in order to analyze the data, we employed the six-step research synthesis model of Roberts', the steps include: 1. Identify need/request, conduct preliminary search, clarify request, 2 . Conduct the search for and retrieval of studies. 3. Selecting, screening, and organizing studies, 4 . Determining the conceptual framework and fitting it to the information from the analysis, 5. Developing the synthesis and interpretation into a material product, 6 . Delivering the results of synthesis. MAXQDa10 software was also used to encode the data. To ensure that the coding process is done correctly, four evaluators were employed to re-encode the findings. They utilized the Scott method (31), and came to an agreement of 86 percent in regard to the coding.

$$
C . R=\frac{62+58+65+71}{4 \times 74} \times 100=86 / 48
$$

$$
C \cdot R=\frac{\text { Number of agreed upnon cate gories }}{\text { Total number of categories }} \times 100
$$

\section{Results}

In this section, according to Roberts' six stage model, each of the stages is analyzed:

\section{Identify need/request, conduct preliminary search, clarify request}

Following the ethics in educational organizations is considered an indispensable principle (26). Teachers, on the other hand, are the most noticeable actors in educational systems (13). Improving teachers' work quality is a key element in improving education (17). Various religions pay attention to teachers and their characteristics. Accordingly, Islam has paid special attention to teachers and their moral characteristics. The holy book of Qur'an, practical behaviour of the Prophet Muhammad and also of Imams (A) are considered as the main source for understanding Islamic educational perspectives. Considering these, recognizing the moral 
codes of teachers according to the Holy Quran and the narratives of Imams is of utmost importance.

\section{Conduct the search for retrieval of studies}

This stage deals with searching for those kinds of sources that are related to the main need of research (32). Therefore, firstly, all valid scientific articles are selected through searching with keywords such as: the moral characteristics of the teacher from the perspective of the Holy Quran, the practical behaviors of the Imams and their view on the teachers' morality, the moral characteristics of the teacher in view of the Prophet of Islam in databases such as; Sid, Normagas, Magiram, Comprehensive Portal of Human Sciences, Iran Institute of Information Science and Technology and Elmnet Persian Scientific Search Engine, as well as other databases such as Scopus, Emerald, Sage, Scientific Information Database, Science Direct, ProQuest, Springlink, Worldscientific, Taylor \& Francis, Google Scholar, Eric, and Wiley. Afterwards, the relevant sources were preserved and unrelated ones were removed according to the purpose of the research. In order to improve the quality of the work, the articles were searched separately by two people who were fully acquainted with search methods and information resources. This research is conducted based on published scientific-research articles and the selection of this category of sources is due to the fact that scientific-research articles undergo a specialized peer-reviewed process by the supervision of specialized reviewers, which points to the validity of their results.

\section{Selecting, screening, and organizing studies}

This stage is dedicated to judging which studies are relevant to the knowledge requirements. This judging phase needs a development of a criteria for selecting and classifying studies (33). The inclusion criteria for this research are as follows:

1- Articles published in the field of teachers' professional ethics from the perspective of the Quran and the practical behaviour of Imams (a) and the Prophet of Islam.

2. Research should report sufficient data and information regarding research objectives.
3. Research that conducts the specialized review process under the supervision of qualified judges and are in the form of a published article either online or in paper.

In respect to the body of research, 63 studies were conducted in line with the criteria so as to be considered for this research, and some of them were not suitable for the final analysis and were excluded accordingly. The criteria for their exclusion include as follows:

1- Research that did not report sufficient information about the objectives of this research.

2. Research that lacked the necessary scientific quality and was published in predatory journals and conferences.

Accordingly, the process of reviewing research obtained these results: A selection of a body of research with a total sum of 63 studies chosen in regard to the keywords; omission of 21 unrelated research after reviewing their titles; omission of 8 unrelated research after reviewing their abstracts; omission of 8 unrelated research after reviewing their body of research; finally a total sum of 26 research which were considered relevant and were selected in this study.

Determining the conceptual framework and fitting it to the information from the analysis. This stage is a linking framework around which the obtained information is synthesized (33), consequently, the conceptual framework formed in this research revolves around two main concepts:

1- The practical behaviour of Imams (a): this includes any kind of behavior of Imams (a) and the Prophet of Islam with an intention to influence the knowledge, attitude, ethics and behavior of others, including Muslims and non-Muslims, companions, children, adults, their families children and others; no matter in their houses, mosques, alleys and bazaars or anywhere else (34).

2- The Holy Quran: It is the Holy Book of Islam, which was revealed from God to the Prophet $\mathrm{Mu}-$ hammad.

3. Professional ethics: Professional ethics refers to issues, principles and moral values governing a professional system (22). 


\section{Developing the synthesis and interpretation into a material product.}

Based on the findings of the body of research related to the purpose of this research, first all the components are extracted through the open coding process; Therefore, according to the process of encoding in the first stage, in this section, we tried first to identify the components of teachers' professional ethics from the perspective of Islam according to the code of each article, and ordered them in Table 1.

\section{Table 1: Open Encoding}

\begin{tabular}{|c|c|}
\hline Refrence & Teachers' professional ethics from the perspective of the Holy Quran and Islamic narratives \\
\hline (35) & $\begin{array}{l}\text { Being mindful, religious jurisprudence, a continuous tendency to acquire knowledge and experience, avoiding negligence, } \\
\text { admitting to the unbeknown, avoiding concealment of science, avoiding nepotism and discrimination, pioneering in practice, } \\
\text { compensating for mistakes, purity in intention, beginning to speak in the name of God, seeking help from God, deep emo- } \\
\text { tional connection, love and kindness, generosity and openness, empathy and brotherhood, kindness and intimacy with learn- } \\
\text { ers, respect for inclusiveness, humility, good morals, patience, repentance, fidelity, benevolence, neatness, getting to know } \\
\text { their audience, having an understanding of age requirements, paying attention to individual differences, timely training, holis- } \\
\text { tic, cultivating reasoning, knowledge and science, cultivating religiously, nurturing learners' morals, paying attention to the } \\
\text { need for entertainment, choosing appropriate content for education, providing useful content for a better life, providing new } \\
\text { and interesting content, encouraging, facilitating and tolerating, avoiding conflict, forgiveness, avoidance of too much blame, } \\
\text { avoidance of physical violence, seriousness when it is necessary, motivation and appropriate expression. }\end{array}$ \\
\hline (36) & $\begin{array}{c}\text { comprehensive attention attraction, a change in expression, attention to summaries and results, and guiding human beings in } \\
\text { various ways }\end{array}$ \\
\hline$(37)$ & $\begin{array}{l}\text { Following the principle of moderation in education, paying attention to the principle of practicing science, and of freedom, } \\
\text { having a scientific spirit and assigning tasks that commensurate with ability }\end{array}$ \\
\hline (38) & $\begin{array}{l}\text { Kindness toward the trainee, apparent charm and neatness, encouraging trainees to take moral actions, encouraging thinking } \\
\text { in respect to the moral issues, enjoining virtues and forbidding vices, continuous supervision and care, getting to know the } \\
\text { trainee's spirit, forgiveness and overlooking faults, being firm with the trainee in case it is necessary. }\end{array}$ \\
\hline (39) & $\begin{array}{l}\text { Love, determination and dignity in educating trainee, providing a model of education and having a practical pedagogy, en- } \\
\text { couraging and preaching, dealing with religious pedagogy and proper interaction with the child }\end{array}$ \\
\hline$(40)$ & Providing liberty and being responsible \\
\hline$(41)$ & $\begin{array}{l}\text { Provide a model, paying attention to the rational and emotional aspect of the trainee, honesty, benevolence, humility and } \\
\text { flexibility of the trainer, preacher, adapting the training process with the needs and moods of the trainee }\end{array}$ \\
\hline$(42)$ & $\begin{array}{c}\text { Repeating lessons and their content, good mood, having a communication with the learner, accurate expression, and creativ- } \\
\text { ity in practice, individual self-awareness and attention to social awareness, attracting audiences and stimulating thought and } \\
\text { thinking. }\end{array}$ \\
\hline (43) & $\begin{array}{c}\text { No discriminatory behavior, respecting children personality, attention to emotions, understanding the child's situation, ra- } \\
\text { tional education, love, lack of humiliation and ridicule, and no blaming }\end{array}$ \\
\hline (44) & Moral example \\
\hline (45) & $\begin{array}{l}\text { Paying attention to science in action (practical and not just verbal promotion), asking students accurate questions and an- } \\
\text { swering them, kindness and humility, neatness, non-discrimination in attitudes and paying attention to appropriate way of } \\
\text { finding friends. }\end{array}$ \\
\hline (46) & $\begin{array}{l}\text { Finding one to be responsible toward those who seek knowledge, respecting the intrinsic values of the trainee, paying atten- } \\
\text { tion to the pervasive power, testing the student appropriately, warning before disciplining and stating the reason behind do- } \\
\text { ing something }\end{array}$ \\
\hline
\end{tabular}




\begin{tabular}{|c|c|}
\hline$(47)$ & $\begin{array}{l}\text { Respect for the learner, tolerating them, kindness toward the trainee, comprehensive attention to the details of a task, moder- } \\
\text { ation with the learner, providing a model for a learner, encouragement and disciplining, empathy and practical training. }\end{array}$ \\
\hline$(48)$ & $\begin{array}{l}\text { Using easy-to-grasp teaching methods, emphasizing important topics, attracting the audience's attention, and appropriate } \\
\text { disciplining and avoiding discrimination. }\end{array}$ \\
\hline$(49)$ & $\begin{array}{c}\text { Tolerance, patience, logical reasoning, no discrimination toward trainee's attitudes, fairness, getting to know trainee, freedom } \\
\text { of thought and having an inclusive expression. }\end{array}$ \\
\hline$(50)$ & Fair and proportionate disciplining, love and kindness \\
\hline$(51)$ & Good morals, having an eloquent and noble speech, promoters of goodness, being cooperative \\
\hline$(52)$ & $\begin{array}{l}\text { Providing liberty and employing no force towards the trainee, fulfillment of promises forgiveness, providing criteria for eval- } \\
\text { uation (evaluation based on criteria), and paying attention to the hereafter and a rejection of materialism and worldliness. }\end{array}$ \\
\hline$(53)$ & $\begin{array}{c}\text { Providing liberty and giving responsibility, paying attention to rational education, self-awareness, kindness, paying attention } \\
\text { to the spiritual and physical dimensions, paying attention to the social dimensions of man, paying attention to natural dimen- } \\
\text { sions, cooperation and collaboration }\end{array}$ \\
\hline (54) & $\begin{array}{l}\text { Kindness and affection toward the audience, respect for the personality of the audience, getting to know audience, attention } \\
\text { to individual differences and their capacity, opportunism in education, providing behavioral model, self-knowledge, attracting } \\
\text { the audience attention to the resolution of affairs }\end{array}$ \\
\hline$(55)$ & Guidance, reasoning, positive interaction, promoting individual and group responsibility \\
\hline (56) & $\begin{array}{l}\text { Insightfulness, passion for science, prompting, gaining experience and learning, acting on time and not neglecting, convinc- } \\
\text { ing and firm in their decision, acting according to wisdom }\end{array}$ \\
\hline$(57)$ & $\begin{array}{c}\text { Needs assessment, assessment with ease, paying attention to wisdom, assessment during teaching, and ease in respect to the } \\
\text { teaching method }\end{array}$ \\
\hline$(58)$ & $\begin{array}{c}\text { Tolerance and kind behavior, seriousness, caring and respectful behavior, encouragement, continuous monitoring during the } \\
\text { process of teaching, paying attention to the growth of all aspects of an inclusive existence, and strengthening the spirit of } \\
\text { learners and their self-reliance }\end{array}$ \\
\hline$(590$ & $\begin{array}{c}\text { Self-awareness, inclusive cognition, continuous monitoring during the process of learning, empathy, seeking attention, and } \\
\text { timely encouragement and disciplining. }\end{array}$ \\
\hline$(60)$ & $\begin{array}{l}\text { Timely and proportionate disciplining, kindness and affection, no discrimination in dealing with children, respect for chil- } \\
\text { dren's personality, proper encouragement, continuous monitoring during the process teaching, paying attention to children's } \\
\text { independence and self-reliance. }\end{array}$ \\
\hline
\end{tabular}

\section{Delivering the results of synthesis}

In this section, the ethical codes of teachers are examined from the perspective of Islam according to the process of research synthesis. First, in the research synthesis process, teachers' ethical codes are extracted in such a way that the descriptions of all components are identified through the open coding process. Then, since the purpose of the research synthesis during developing the synthesis into a material product is to combine all scientific findings in one specific subject, and achieving coherence, in the presentation of the combination results, first the qualitative analysis of open codes is put together, and through re-encoding, overlap and semantic similarity are combined and the components (axial codes) are extracted. In order to categorize all the components of teachers' professional ethics based on a common concept, axial coding has been employed, which leads to the identification of 2 dimensions of the selective code. The results of the axial and selective coding are presented in Table 2. 
Table 2: Selective coding of teachers' ethical components

\begin{tabular}{|c|c|c|}
\hline Dimensions & Components & Categories \\
\hline \multirow{23}{*}{$\begin{array}{l}\text { Contextual } \\
\text { Dimensions }\end{array}$} & \multirow{9}{*}{$\begin{array}{l}\text { Personality } \\
\text { traits }\end{array}$} & Kindness \\
\hline & & Openness and cheerfulness \\
\hline & & Good morale \\
\hline & & Patience and forbearance \\
\hline & & Gracious \\
\hline & & Humble \\
\hline & & Fulfillment of promise \\
\hline & & Paying attention to compensation \\
\hline & & Honesty \\
\hline & \multirow{7}{*}{ Insight } & Mindfulness \\
\hline & & Religious jurisprudence \\
\hline & & Admitting to the unbeknown \\
\hline & & Avoiding concealment of science \\
\hline & & Logical reasoning \\
\hline & & Understanding needs of an era and opportunism \\
\hline & & Practicing wisdom \\
\hline & \multirow{7}{*}{$\begin{array}{l}\text { Religious com- } \\
\text { mitment }\end{array}$} & Paying attention to religious cultivating \\
\hline & & Seeking help from Allah \\
\hline & & Initiating a task in the Name of Allah \\
\hline & & Religious and moral model \\
\hline & & Purity of intentions \\
\hline & & Finalism and paying attention to the hereafter \\
\hline & & Pay attention to the innate aspects \\
\hline & \multirow{4}{*}{$\begin{array}{l}\text { Socio-political } \\
\text { dimension }\end{array}$} & Avoid political partisanship \\
\hline & & Pay attention to social consciousness \\
\hline & & Pay attention to one's social interactions \\
\hline & & Feeling obligation in regard to the knowledge seekers \\
\hline
\end{tabular}


Pourshafei H. et al.

International Journal of Ethics \& Society (IJES), (2020) Vol. 2, No. 3

\begin{tabular}{|c|c|c|}
\hline & & Being cooperative \\
\hline & Neatness & Being neat \\
\hline \multirow{27}{*}{$\begin{array}{l}\text { Professional di- } \\
\text { mensions }\end{array}$} & \multirow{16}{*}{$\begin{array}{c}\text { Professional } \\
\text { principles }\end{array}$} & Being holistic \\
\hline & & Cultivating reason and wisdom \\
\hline & & Pay attention to individual differences \\
\hline & & Getting to know one's audience \\
\hline & & Respecting the trainer \\
\hline & & Fostering the ethics of learners \\
\hline & & Paying attention to the moderation principle \\
\hline & & Paying attention to the freedom principle \\
\hline & & Self-consciousness \\
\hline & & Paying attention to the principle of tolerance \\
\hline & & Paying attention to science in action \\
\hline & & Promoting virtue and preventing vice \\
\hline & & Paying attention to continuity in care \\
\hline & & Creativity in practice \\
\hline & & Stating the reason behind doing something \\
\hline & & Paying attention to emotions and pervasive feelings \\
\hline & \multirow[t]{3}{*}{ Interactions } & Deep emotional relationship \\
\hline & & Empathy and brotherly relations \\
\hline & & Fondness with trainee \\
\hline & \multirow{4}{*}{$\begin{array}{l}\text { Content man- } \\
\text { agement }\end{array}$} & Choosing the right content \\
\hline & & Providing interesting content \\
\hline & & Provide useful content for life \\
\hline & & Presentation of up-to-date content \\
\hline & \multirow[t]{4}{*}{ Teaching } & Appropriate wording and expression \\
\hline & & $\begin{array}{l}\text { Paying attention to the need for games and entertain- } \\
\text { ment in teaching }\end{array}$ \\
\hline & & Summarizing and providing conclusions \\
\hline & & Pay attention to pervasive self-reliance \\
\hline
\end{tabular}




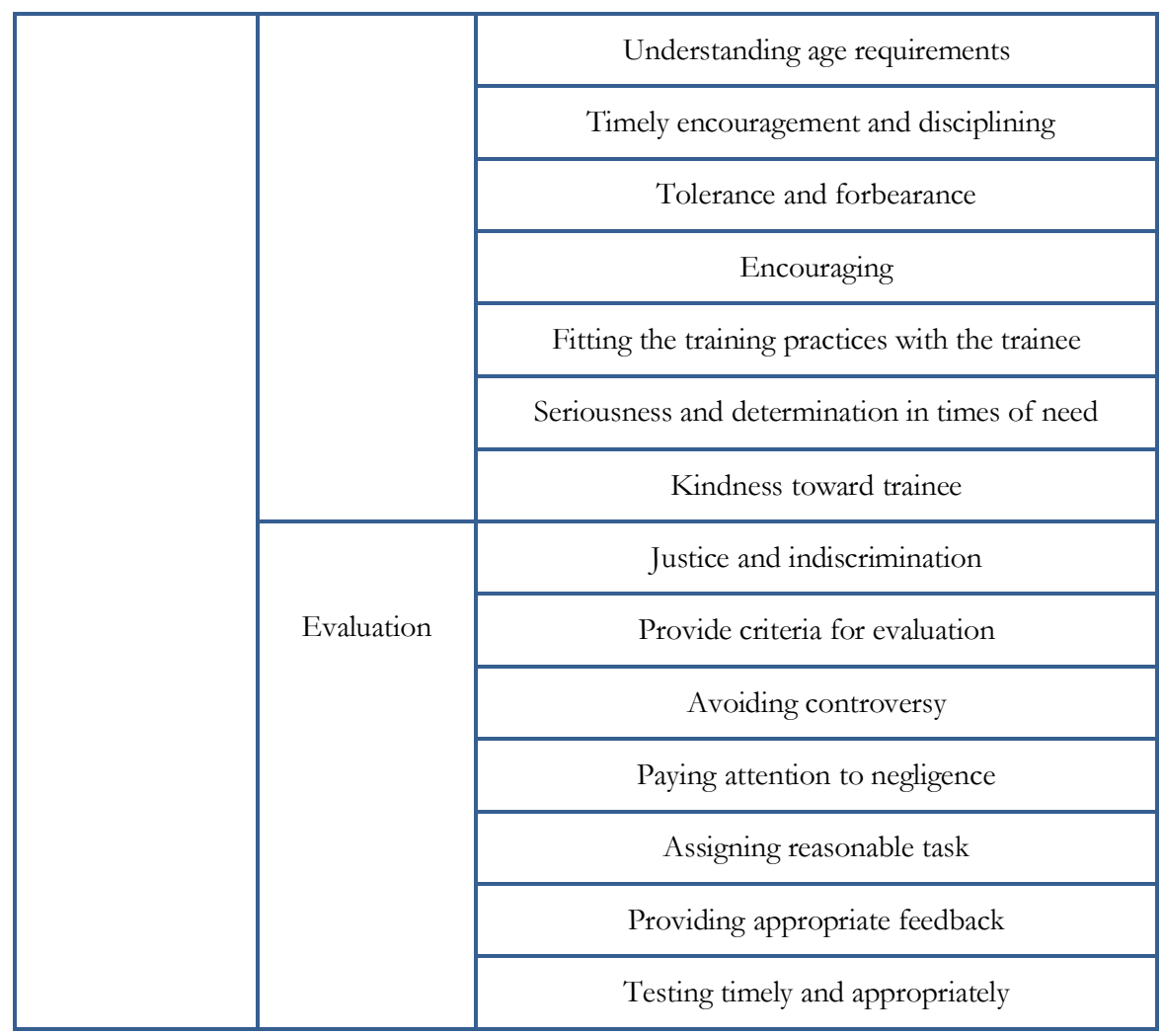

\section{Discussion}

Since all the known factors and categories for the components of teachers' professional ethics are placed in the contextual and professional dimensions, all factors are organized under these sets of dimensions.

Contextual dimensions: This dimension of teachers' ethical codes is related to all factors of a teacher's personality. Individual factors and characteristics are among influential components in relation to the teachers' professional ethics (24). In Islam, the individual and personality dimensions of the teacher are noteworthy given that they are considered as role model in the eyes of the learners. In the present study, the components of professional ethics of teachers in this dimension were organized in several categories: personality traits, insight, religious commitment, socio-political dimension and apparent neatness. In this regard, other researchers have found findings in line with the findings of the intended dimension, such as honesty in the teacher's speech and actions (61), humility and modesty (62), tolerance and forbearance (63), commitment to religious values (64) and appropriate clothing (65).

Professional dimensions: Today, observing professional ethics in organizations is a competitive advantage (24). Teachers' adherence to the principles and values of professional ethics is important, both in terms of developing an ethic-based organizational culture and of transmitting distinctive human traits and characteristics to learners and, consequently, its dissemination in society (11). In this section, according to the principles of Islam, the components of teachers' professional ethics were organized in the fields of: professional commitment, professional principles, knowledge-building, interactions, content management, teaching and evaluation. With a holistic view of findings in this field we can grasp the idea that Islam, besides paying attention to professional dimensions of teaching profession, has paid special attention to the moral characteristics of teachers in each of their job duties. This notable fact is also evident in other divine religions. Judaism has placed special emphasis on the professional ethics of teachers, so 
that in the laws of the Torah it is stated that no one can absolve himself of the responsibility of not realizing educational potentialities and abilities, and if a person has the characteristics of a teacher, then teaching is an obligation for $\mathrm{him} / \mathrm{her}(28)$. In terms of teachers' code of ethics, other research have also mentioned some of these cases: being interested in the teaching profession (63), respecting the dignity of learners and adjusting content with their needs (66), appropriate interactions (67), using appropriate teaching methods (68), impartiality in times of evaluation (69), standard evaluation (70) and attention to individual differences (71).

\section{Conclusion}

Observance of ethics and ethical roles in educational organizations is one of the organizational requirements. This is of increasing importance due to the role that teachers have as models and their effects on learners. Many moral codes have been stated for teachers. Among them, the divine religions have paid special attention to professional ethics in teaching. The religion of Islam, due to its great educational foundations, has considered many moral components for educators, and stated that paying attention to them will improve the educational process of learners. Findings of the present study classify the moral dimensions of teachers of Islam in two general categories of contextual dimensions (factors related to the personality traits of educators) and professional dimensions (factors related to the professional duties of educators). According to the findings of this study, the following suggestions are provided to improve the professional ethics of teachers.

1 -In-service courses should be held in educational organizations to explain the view of Islam towards the moral codes of teachers.

2- The moral codes of ethic of teachers should be designed according to the moral codes considered in Islam.

\section{Ethical Consideration}

Ethical issues (including plagiarism, informed consent, misconduct, data fabrication and/or falsification, double publication and/or submission, redundancy, etc.) have been completely observed by the authors.

\section{Acknowledgement}

This study is an extract from a doctoral dissertation thesis (code number \# 1563535) approved at the University of Birjand, but the design of the study, data collection, analysis, interpretation and writing were entirely the responsibility of the authors. We are grateful to all those who helped us with this research.

\section{References}

1. Selajgeh A, Safari S (2015). The relationship between professional ethics and the performance of university professors. Ethics in Science \& Technology, 10 (3): 103-110. (In Persian)

2. Salimi A, Rahimipour S (2012). The place, importance and relationship between cultivation and teaching in the educational topics of the Holy Quran. Research-Letter of Quranic Education, 3 (9): 66-51. (In Persian).

3. Majlisi MB (1984). Reference of the intellect in the description of the news of the messenger. Islamic Library, Tehran/ Iran. (In Persian).

4. Nasiri Valik Nabi F, Navidi P (2016). The relationship between professional ethics and organizational agility: the mediating role of cognitive empowerment. Ethics in Science \& Technology, 12 (2): 61-69. (In Persian).

5. Morris L, Wood G (2013). A model of organizational ethics education. Joumal of European Business Review, 23(3): 274286.

6. ÜNLÜ M (2018). An evaluation of occupational ethical values of geography teacher candidates in Turkey. Educational Research and Reviens, 13(2): 68-73.

7. Sanger $M N$ (2008). What we need to prepare teachers for the moral nature of their work. Journal of Curriculum Studies, 40: 169-185.

8. Maxwell B (2017). Codes of professional conduct and ethics education for future teachers. Philosophical Inquiry in Education, 24 (4): 323-347. 
9. Rissanen I, Kuusisto E, Hanhimäki E, Tirri K (2018). The implications of teachers' implicit theories for moral education: a case study from Finland. Journal of Moral Education, 47(1): 63-77.

10. Tirri $K$ (2014). The last 40 years in Finnish teacher education. Journal of Education for Teaching, 23(1): 1-10.

11. Ardalan MR, Beheshti Rad R (2016). The relationship between the moral atmosphere of the organization and educational ethics; the mediating role of professional development. Ethics in Science \& Technology, 11 (4): 1-12. (In Persian).

12. Nemati MA, Mohseni H. (2010). Ethics in higher education: components, requirements and strategies. Strategy Quarterly, 63: 9-46. (In Persian).

13. Balyer A, Özcan K (2014). Choosing teaching profession as a career: students' reasons. International Education Studies, 7(5): 104-115.

14. Alsubaie MA. (2016). Curriculum development: teacher involvement in curriculum development. Journal of Education and Practice, 7(9): 105-107.

15. Harris DN, Tim R (2011). Teacher training, teacher quality and student achievement. Journal of Public Economics, 95 (1): 798-812.

16. Pourshafei H, Gholampour M (2019). An introduction to professionalism and teacher professional development. The Publication of Four Trees, Birjand/ Iran. (In Persian).

17. Gholampour M, Pourshafaei H, Ghasemian A (2019). Considering the role of culture and organizational voices on teachers' professional ethics. International Journal of Ethics \& Society (IJES), 2(1): 1-9.

18. Ghaemi M, Shariatmadari M (2017). The relationship between professional ethics and confidence building among faculty members. Ethics in Science \& Technology, 12 (4): 1-10. (In Persian).

19. Sobhani Nejad M, Najafi H, Jafari Harandi R, Farmihni Farahani M (2014). Components of professional teaching ethics from the students' point of view. Journal of Qom University of Medical Sciences, 7 (6): 399-403. (In Persian).

20. Yildız ML, Eti I, Ercan Gegez A (2013). Perceived academic code of ethics: a research on Turkish academics. Procedia - Social and Behavioral Sciences, 99(1): 282-293.

21. Wines WA (2008). Seven pillars of business ethics: towards a comprehensive framework. Journal of Business Eth$i c s, 79$ (4): 483-499.

22. Miller FG, Emanuel EJ, Rosenstein DL, Strauss SE. (2004). Ethical issues conceming research in complementary and alternative medicine. JAMA, 291 (5): 599-604.

23. Imanipour M (2012). Principles of professional ethics in education. Medical Ethics and History, 5 (6): 27-41. (In Persian).
24. Mohammad Davoodi AH, Bahadori S (2017). Determining the effective factors on the effectiveness of professional ethics from the perspective of teachers in Qom province. ANew Approach in EducationalManagement, 8 (31): 165-186. (In Persian).

25. Bullough RV (2011). Ethical and moral matters in teaching and teacher education. Teaching and Teacher Education, 27(1): 21-28.

26. Davenport M, Thompson JR, Templeton, NR (2015). The teaching of the code of ethics and standard practices for Texas educator preparation programs. NCPE A International Journal of Educational L eadership Preparation, 10(2): 8295.

27. Azarmi S, Farzan F, Amimejad S (2016). Investigating the relationship between spiritual intelligence and organizational citizenship behavior in physical education teachers in Ardabil province. Sports Management and Motor Behavior Research Joumal, 12 (24): 69-84. (In Persian).

28. Rashi $T$ (2019). Ethics for teachers in Judaism. Ethics and Education, 14(1): 36-53.

29. Forouzeh S, Mohsenizadeh M (2014). Components of religious education and its methods in the lifestyle of Imam Reza (as). National Conference on Lifestyle in Razavi Culture, Mashhad/ Iran. (In Persian).

30. Cooper H, Hedges L V. (2009). Research synthesis as a scientific process. In: H Cooper, LV Hedges, JC Valentine (Ed.). The handbook of research synthesis and meta-analysis. Russell Sage, USA. Pp. 3-16.

31. Scott W (2012). Theory of financial accounting. Translated by: Parsaeean A. Terme Publication, Tehran/ Iran. (In Persian)

32. Prashar A. (2015). Assessing the flipped classroom in operations management: a pilot study. Joumal of Education for Business, 90(3): 126-138.

33. Moffett, J. (2015). Twelve tips for "Flipping" the classroom. Medical Teacher, 37(4): 331-336.

34. Nikkhah M, Nasr Esfahani AR, Azizi H (2011). Skills and methods of teaching and learning in the teachings of the prophet (PBUH) and the Ahl al-Bayt (AS). The First National Conference on Fundamental Transformation in the Iranian Curriculum System, Mashhad/ Iran. (In Persian).

35. Vajdani $F(2010)$. Coach characteristics from the perspective of narratives. Research and Thought, 17 (4): 123-143. (In Persian).

36. Mardani M H, Yuzbashi A, Norouzi M (2010). Analytical study of instances of educational and training innovations in the Holy Quran. Studies of Quran and Hadith, 3 (2): 99124. (In Persian).

37. Beheshti S, Rashidi S. (2013). Principles of rational education based on the words of Imam Reza (as). Research on Islamic Education, 18: 51-67. (In Persian). 
38. Najafi M, Victim M, Nosrati K, Shahi M (2014). Methods of moral education in Sira Razavi (AS). Ethical Research, 5 (1): 113-127. (In Persian).

39. Azimzadeh Ardabili F, Hamidipoor M (2014). Mechanisms to support the upbringing of children in religious teachings with emphasis on the Razavi tradition. Sira Razavi Journal, 2 (5): 141-167. (In Persian).

40. Shariati SD, Insafi Mehrabani S. (2014). A look at determinism and free will in the school of Islam and its educational implications. Joumal of Quranic Knowledge, 5 (17):7-29. (In Persian).

41. Bagherinia H (2014). Preaching method: challenges and injuries with emphasis on Quranic teachings. Quranic Education Research Journal, 5 (16): 57-75. (In Persian).

42. Jaloudar H, Patiar E (2014). The purpose of persuasion in education with emphasis on the story of prophet Ibrahim (AS). Quran Education Research Journal, 5 (19): 7-30. (In Persian).

43. Hosseinzadeh A, Ghasemi Gotari H (2015). Explaining the most important methods of training in traumatic education based on the verses of the Holy Quran and the Hadiths of the Imams (as). Journal of Quranic Education, 6 (22): 55-79. (In Persian).

44. Nikayin M, Bakhtiar Nasrabadi HA, Bahrami H, Nosrati Hashti K, Abbaspour N (2015). Imam Reza's educational works in the excellence of the spiritual beliefs of the Iranian people. Razavi Culture, 3 (12): 97-118. (In Persian).

45. Ali Dokht Mazafei H, Seifi Jagarkandi M, Yousefzadeh M, Kheiri M (2015). Social education in the life of Imam Reza (as). The $1^{\text {st }}$ National Conference on New Research in the Field of Humanities and Social Studies in Iran, Mashhad/ Iran. (In Persian).

46. Shahroudi M R, Nourani Negar M. (2015). Student etiquette in reciting verses related to Moses and Khidr. Research on the Qur'an and Hadith, 48 (1): 65-78. (In Persian).

47. Omrani M, Afsardir H, Sadat Omrani M (2015). Strategies for social and emotional education of adolescents in the Quran and Hadiths. Journal of Quranic Education, 6 (23): 7 34. (In Persian).

48. Ghotbi S, Rahnama A, Pak Rahbari N, Najafi H (2016). Analysis of Imam Reza's (AS) educational methods based on the position of Imam Reza (AS). Razavi Culture Quarterly, 4 (10): 47-69. (In Persian).

49. Delbari S, Zahmatkesh Z (1396). Applying tolerance and tolerance methods in Imam Reza's (a) educational life. Sira Razavi, 5 (20): 31-67. (In Persian).

50. Zargoosh Nasab A J, Jalilian F (2016). Punishment of the child for education and discipline from the perspective of hadiths. Educational Teachings of Quran and Hadith, 2 (4): 7792. (In Persian).
51. Morvati S, Nasrabadi F, Akbarnejad M, Hosseiniania M R, Rasouli A. (2016). Educational components of the perspective of a religious community based on the Qur'an and Hadith. Educational Doctrines in the Qur'an and Hadith, 2 (4): 41-58. (In Persian).

52. Ismailzadeh M, Aboutorabi M, Hosseinizadeh A, Bakuei M (2016). Principles of comparative education in the teachings of the Qur'an. Educational Teachings in Quran and Hadith, 2 (3): 39-55. (In Persian).

53. Mohammadi R, Fiqhizadeh A (2016). Fundamentals of anthropology the educational method of Quran and Hadith in the social dimension. Educational Doctrines in the Qur'an and Hadith, 2 (3): 1-18. (In Persian).

54. Sharifi E, Khawaninzadeh MH, Khalatbari H (2017). Imam Reza's (a) educational methods. Razavi Culture, 5 (19): 149-176. (In Persian).

55. Dehghan Sorkhabadi MH, Keramati E (2017). Educational methods in the Razavi tradition and its implications for rational education at Farhangian University. Sira Razavi, 5 (17): 35-57. (In Persian).

56. Rahmani N, Pourkarimi J, Dialmeh N, Khanifar H (2017). Principles and methods of education based on wisdom from the perspective of the Holy Quran and the narrations of the Ahl al-Bayt (AS). Educational Teachings of Quran and Hadith, 3 (2): 107-123. (In Persian).

57. Zakiazadeh Ranani AR, Ebrahim Najafabadi M (2017). Rational education in the teaching method of Khidr PBUH. Educational Teachings of Quran and Hadith, 3 (5): $37-$ 50. (In Persian).

58. Mirza Mohammadi MH, Jahan Javanmardi F, Norouzi M. (2017). Recognition of Imam Reza's (AS) educational teachings and its application in the present age. Farhang $\mathrm{R} a$ zavi, 5 (20): 69-104. (In Persian).

59. Nowruz M, Kazemi A, Shahmoradi S F (2017). Strategies for religious education in cyberspace with emphasis on the teachings of the Qur'an and the Razavi tradition. Razavi Culture, 5 (19): 177-211. (In Persian).

60. Sharifi E, Lotfi Q (2018). Imam Reza's (PBUH) educational style in raising children. Razavi Culture, 6 (3): 181-211. (In Persian).

61. Boon H, Maxwell B (2016). Ethics education in Australian preserve teacher programs: a hidden imperative? Australian Journal of Teacher Education, 41(5): 1-20.

62. Chapman A, Forster D, Buchanan R. (2013). The moral imagination in pre-service teachers' ethical reasoning. Australian Joumal of Teacher Education, 38 (5): 131-143.

63. Al-Hothali HM (2018). Ethics of the teaching profession among secondary school teachers from school leader's perspective in Riyadh. International Education Studies, 11(9): 47-63. 
64. Abbasi R, Taheri Gh, Baba Shahi J (2017). The state of professional ethics of professors from the students' point of view. Ethics in Science and Technology,12 (4): 1-10. (In Persian).

65. Moradi Doliskani M, Saeedi Rezvani M, Karami M, Aminkhandaghi M (2016). Identifying the standards and components of professional ethics for teaching teachers of Islamic education courses. Culture at the Islamic University, 6 (4): 473-494. (In Persian).

66. Boon H (2011). Raising the bar: ethics education for quality teachers. Australian Journal of Teacher Education, 36(7): 104-121.

67. Akcamete G, Kayhan N, Yildirim A E S. (2017). Scale of professional ethics for individuals working in the field of special education: validity and reliability study. Cypriot Journal of Educational Science, 12(4): 202-217.

68. Motalefard AR, Nave E, Ebrahim M (1390). Study and identification of professional and ethical indicators in education and teaching from the perspective of graduate students. Ethics in Science and Technology, 6 (4): 1-9. (In Persian).

69. Pinar I (2002). Research for academician value ethics. Journal of Business Ethics, 43(13): 23-32.

70. Seghedin E (2012). Communication - the main component of teaching competence. Procedia - Social and Behavioral Sciences, 69: 350-358.

71. Mundy M A, Kupczynski L, Ellis J D, Salgado R L(2009). Setting the standard for faculty professional development in higher education. Journal of Academic and Business Ethics, 2(1): 1-9. 